\title{
A review of cardiovascular and renal function monitoring: a consideration of older adults with HIV
}

This article was published in the following Dove Press journal:

HIVIAIDS - Research and Palliative Care

13 September 2013

Number of times this article has been viewed

\author{
Clark D Kebodeaux' \\ Alexandria Garavaglia \\ Wilson' \\ Daron L Smith ${ }^{2}$ \\ Scott Martin Vouri' \\ 'St Louis College of Pharmacy, \\ Division of Pharmacy Practice, \\ St Louis, MO, USA; ${ }^{2}$ St Louis College \\ of Pharmacy, Adjunct Faculty, \\ St Louis, MO, USA
}

\begin{abstract}
The prevalence of human immunodeficiency virus (HIV) infection in older and elderly adults is significant worldwide. This population poses new challenges and opportunities in the management of HIV. In addition to the risks affecting HIV patients of all ages, including risk of opportunistic infection and medication resistance, age-related changes in physiology, higher comorbidity burdens, increased use of medications, and potential adverse drug reactions to HIV medications all factor into the care of older adults with HIV. The risk and progression of cardiovascular and renal comorbidities may be higher in the older adult HIV population and in patients taking specific HIV medications. Understanding these risks is essential when managing a new type of patient: the older adult with HIV.
\end{abstract}

Keywords: older adult, elderly, geriatrics, cardiovascular disease, kidney disease, renal dysfunction, HIV

\section{Introduction}

When discussing human immunodeficiency virus (HIV) in older adults, the nomenclature can differ based on the source of information. Currently, the Centers for Disease Control (CDC) in the United States defines "elderly" in the HIV population as 50 or older; ${ }^{1}$ however, this definition differs from study to study. Most HIV studies have defined people 50 or older as "older adults," while people 60 or older in developing countries and people 65 or older in developed countries are defined as "elderly". ${ }^{2,3}$ For the purpose of this review, "older adults" will be defined as 50 or older and "elderly" will be defined as 65 or older.

Currently, there are 34 million people worldwide with a diagnosis of HIV. ${ }^{4,5}$ In 2006 , $15.5 \%$ of the patients diagnosed with HIV were 50 or older; this percentage has doubled since 1982. ${ }^{4,6}$ Additionally, 25\% of patients with a diagnosis of HIV (independent of the age at diagnosis) were 50 or older, which is an increase of $17 \%$ over 5 years. It is estimated that more than $50 \%$ of the worldwide HIV population will be 50 or older by the year $2015 .^{7}$ The addition and evolution of highly active antiretroviral therapy (HAART) is a large contributing factor to HIV-infected adults living longer. ${ }^{2}$ When optimal care and combination antiretroviral therapy (cART) are utilized, patients are expected to live an additional 20 years, to a near-normal lifespan. ${ }^{2,8}$ In women, the rate of HIV diagnosis is decreasing in all age cohorts except for those 50 or older. ${ }^{9}$ Moreover, race and ethnicity assessments in the United States show the rate for HIV infection in older adults disproportionately affects African Americans 12 times more than Caucasians. ${ }^{10,11}$
Correspondence: Scott Martin Vouri St Louis College of Pharmacy, 4588 Parkview Place, St Louis, MO 63110, USA

$\mathrm{Tel}+|3| 4446855 \mid$

$\mathrm{Fax}+\mathrm{I} 3144468500$

Email scott.vouri@stlcop.edu 
Although only identified in descriptive data, there is limited information available for "elderly" patients. In an abstract from a French HIV database ( $\mathrm{n}=1,680$ patients), $3.87 \%(n=61)$ were 65 or older. ${ }^{12}$ Of these patients, $21 \%$ were women and $79 \%$ were men; regarding the status of these patients, $38 \%$ had an acquired immunodeficiency syndrome (AIDS)-defining illness, 21\% were symptomatic, and 41\% were asymptomatic. ${ }^{12}$ The initial diagnosis of patients 65 or older worldwide ranges from $1.8 \%-2 \%{ }^{13-16}$ In the United States, the CDC has also compiled data for elderly patients with HIV. ${ }^{9}$ From 2008 to 2011, the diagnosed incidence in this age group was 2.0-2.4 per 100,000. When evaluating elderly patients currently living with HIV, the rate is 85.7 per 100,000 persons, which is just one-ninth of the cohort (45-49 year olds) with highest rate of infection. ${ }^{9}$

Many older adults do not consider the risk of acquiring HIV. In a 2010 HIV Surveillance Report published by the CDC, approximately 21,000 "older adults" remained undiagnosed: $10.1 \%$ of all undiagnosed HIV patients. ${ }^{17}$ There are two main factors that may contribute to a lack of an HIV diagnosis. The first is a lack of testing. Currently, the $\mathrm{CDC}$ recommends universal opt-out testing in persons aged 13 to 64 . Previously, patients 65 or older were not considered for routine testing because of the increased costs of testing in this population and the low proportion of the elderly thought to be infected with HIV. ${ }^{2}$ However, the American College of Physicians, the American Academy of HIV Medicine, the American Geriatric Society, and the AIDS Community Research Initiative of America recently updated their guidelines to recommend no upper age limit for HIV testing. ${ }^{9,10}$ The second factor contributing to a lack of diagnosis in older HIV patients is the inability to differentiate symptoms of HIV from symptoms of "typical aging". 9 These symptoms may include dementia, weight loss, fatigue, anorexia, chronic pain, rash, and itching. ${ }^{8,9,13}$ Failure to assess risk factors, or patients not fully disclosing risk factors, can prolong the time to diagnosis. Therefore, an accurate history of patients' intercourse and intravenous drug use needs to be solicited regardless of age. ${ }^{9}$ When people 50 or older were compared to 20 year olds, older adults were 5 times less likely to be tested and were 6 times less likely to use condoms during intercourse. $^{18}$

Once diagnosed, the prognosis and course of HIV in older adults differs from that in younger counterparts. At diagnosis, older adults typically have lower CD4 counts, approximately $15 \%$ less than younger adults, which is thought to result from an increased time to diagnosis and age-related immunological

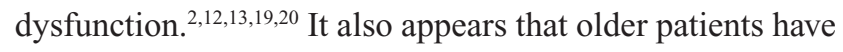

a greater virologic response to cART than younger patients; however, their immune response is weaker. Therefore, older adults show a quicker decrease in viral load, with a conversely slower increase in CD4 nadirs. ${ }^{21}$

Additionally, older adults are at higher risk for worse outcomes because of neurocognitive decline, social isolation, lack of social support, and depression. ${ }^{22}$ After HIV diagnosis, cART is usually initiated sooner in older adults. ${ }^{18,20}$ The risk of developing AIDS or death increases by 1.3 and 1.5 times, respectively, for every increase in age by 10 years. ${ }^{9}$ Progression to AIDS and death is highest in the older adult population. ${ }^{2,49}$ The AIDS-defining illness of HIV-related dementia is also highest in older adults. ${ }^{9}$

The shift toward a population of older adults having HIV brings new treatment considerations to light. When assessing an older adult or elderly HIV patient, the health professional must continue to address cART and opportunistic infections; however, further considerations must also be made for agerelated comorbidities such as cardiovascular disease, metabolic disorders, non-HIV related malignancies, osteoporosis, depression, and liver and renal function decline. ${ }^{8,22,23}$

\section{Cardiovascular risk and renal function in older adults}

Cardiovascular disease (CVD) and chronic kidney disease (CKD) are highly prevalent in the elderly population. Currently, there are 40.4 million people in the US over the age of 60 diagnosed with CVD; this population comprises one-half of all CVD cases in the US. ${ }^{24}$ In patients 60 years or older, $73 \%-80 \%$ of men and $72 \%-87 \%$ of women have CVD. Approximately two-thirds of otherwise healthy adults have some decline in renal function. ${ }^{25,26}$ Coresh et al determined that the prevalence of CKD in 60-69 year olds is double that of 40-59 year olds; the prevalence of CKD in adults 65 or older is $38 \%{ }^{27}$

With the increasing number of older adults and the elderly with a diagnosis of HIV, plus the relatively higher prevalence of CVD and CKD in the older adult population, the HIV and Aging Consensus Project published a summary report that highlights specific risk factors that older adults face with concomitant HIV. ${ }^{28}$ This summary report discusses: initiation of cART; prevalence of CVD, CKD, diabetes, and hypertension; drug-drug interactions; hepatitis screening; cancer screening; sexual health; pulmonary disease; osteoporosis; advanced directive care; and mental health. The specific aim of the present paper is to further discuss the cardiovascular and renal considerations in older adults with HIV. 


\section{HIV: impact on cardiovascular function}

Advances in the effective delivery of cART combined with the natural process of aging have raised new questions about risks posed to the older patient with HIV. In a descriptive, cross-sectional analysis of older adults with HIV compared with HIV-positive patients under the age of 50, the frequency of ischemic heart disease, congestive heart failure, vascular disorders, stroke, hypertension, and hyperlipidemia were more prevalent in the older adult cohort. ${ }^{29}$ There is evidence to suggest that the presence of HIV has an adverse effect on various biomarkers related to inflammation and coagulation, regardless of age.$^{30}$ Additionally, other studies have examined the potential link between CVD and HIV. ${ }^{31-33}$ Whereas not all studies have examined this link in older adults, a recent study examined the risk of HIV and myocardial infarction (MI). ${ }^{34}$ After adjusting for comorbidities and cardiovascular risk scores, that study found the associated risk for MI with HIV infected patients was 1.48 (hazard ratio [HR]; 95\% CI, 1.27-1.72). Of note, the population was stratified by age group, and only HIV infected patients between 50-59 years and 60-69 years had a significantly higher incidence of MI than that of uninfected patients. Patients with HIV between 70-79 years and 80-89 years did not have a higher risk for MI than their non-HIV control group.

The specific rationale for cardiovascular risk in aging patients with HIV is not clear. The process appears to be multifactorial. Potential causes include the use of cART, specific use of antiretroviral agents within regimens, the inflammatory nature of HIV disease itself, and the natural process of aging.

\section{cART versus non cART}

There are several studies related to the use of cART and implications for cardiovascular risk. A notable study which found an increased risk for the development of MI was the Data Collection on Adverse Events of Anti-HIV Drugs (D:A:D) study group. ${ }^{33}$ Whereas other variables such as age, smoking status, and male sex were associated with increased risk of MI in the D:A:D cohort, there was an independent association of $\mathrm{MI}$ in patients exposed to cART, with a risk ratio (RR) of $1.26(95 \% \mathrm{CI}, 1.12-1.41)$ per year of exposure. Currier et al assessed coronary heart disease (CHD) based on exposure to cART and found a significantly higher rate of CHD in younger patients (18-33 years of age). ${ }^{31}$ Unlike the D:A:D cohort, this study examined risk of CHD for both men and women of various age groups.
Of particular importance to the older adult with HIV, the study found a significant reduction in CHD incidence in men aged 45-54 years, 55-64 years, and 65-74 years, and in women aged 55-64 years, on cART therapy compared with untreated controls. Other studies have examined the cardiovascular risk with cART and come to a variety of conclusions (Table 1). ${ }^{31-33,35-38}$ In contrast, El-Sadr et al found an increase in cardiovascular, renal, or hepatic failure in the cohort of patients who were not aggressively managed with cART based on a CD4 $>250$ cells $/ \mathrm{mm}^{3}$, which could not be specifically attributed to treatment. ${ }^{37}$

\section{Specific ARTs within regimens}

The D:A:D cohort has accumulated enough data to analyze the association of individual antiretroviral medications with MI. Early studies from the 1990s and early findings from the D:A:D cohort published in 2007 determined that there was an increased risk of MI with the use of protease inhibitors (PI) as a class effect. ${ }^{39-43}$ However, more recent data from the D:A:D cohort found an increased RR of MI with the use of indinavir (RR 1.12; 95\% CI, 1.07-1.18) and lopinavir/ritonavir (RR 1.13; 95\% CI, 1.05-1.21), whereas there was no risk found with nelfinavir or saquinavir. ${ }^{44}$ The French Hospital Database Cohort (FHDC) found an association with $\mathrm{MI}$ and both cumulative and recent exposure to amprenavir/fosamprenavir with or without ritonavir and lopinavir/ritonavir, but not indinavir, saquinavir or nelfinavir. ${ }^{38}$ With the exception of lopinavir/ritonavir, these PIs are used minimally in clinical practice, as evidenced by their place in the Department of Health and Human Services guidelines. ${ }^{45}$ The D:A:D cohort recently acquired enough data to analyze atazanavir and found no association between cumulative exposure and risk of MI ${ }^{46}$ Currently, the cohort lacks the data necessary to assess the effects of darunavir, PI, and raltegravir, an integrase inhibitor. Older non-nucleoside reverse transcriptase inhibitors (NNRTIs), efavirenz and nevirapine, and the nucleoside/nucleotide reverse transcriptase inhibitors (NRTIs) have not been associated with MI in the D:A:D cohort or FHDC..$^{39,43}$ Among the individual NRTIs, didanosine and abacavir have been associated with an increased risk for MI in some, but not all, studies..$^{39,47}$ No association has been found with the less commonly used thymidine analogs zidovudine and stavudine, or lamivudine. ${ }^{38,39}$ Cumulative exposure to didanosine, but not recent or past exposure, was associated with an increased risk of MI in the D:A:D cohort (RR 1.06; 95\% CI, 1.01-1.12), ${ }^{39}$ but no risk was seen in the FHDC (RR 0.91; 95\% CI, 0.82-1.01). ${ }^{38}$ Only the assessment by Bozzette et al analyzed admission 
Table I Major studies of cardiovascular risk in HIV-positive patients with or without cART

\begin{tabular}{|c|c|c|c|}
\hline Study & Population & Design & Outcomes \\
\hline $\begin{array}{l}\text { Currier } \\
\text { et } \mathrm{al}^{31}\end{array}$ & $\begin{array}{l}\text { HIV+ Males }(n=20,742) \\
\text { HIV+ Females }(n=7,77 I) \\
\text { Non-HIV+ Males }(n=970,259) \\
\text { Non-HIV+ Females }(n=2,084,437)\end{array}$ & $\begin{array}{l}\text { Historical } \\
\text { cohort }\end{array}$ & $\begin{array}{l}\text { HIV group RR for CHD by ART or not ART } \\
\text { (Covariate adjusted) } \\
\text { I8-33 y } 2.06(95 \% \mathrm{Cl}, 1.42-2.99 ; P<0.00 \mathrm{I}) \\
34-49 \text { y } \mathrm{I} .08(95 \% \mathrm{Cl}, 0.9 \mathrm{I}-1.28 ; P>0.05) \\
50-65 \text { y } 0.79(95 \% \mathrm{Cl}, 0.63-1.00 ; P>0.05) \\
66 \text { or older } \mathrm{I} . \mathrm{I} 5(95 \% \mathrm{Cl}, 0.65-2.04 ; P>0.05)\end{array}$ \\
\hline $\begin{array}{l}\text { Obel } \\
\text { et } \mathrm{al}^{32}\end{array}$ & $\begin{array}{l}\text { HIV }+(n=3,953) \\
\text { Non-HIV+ }(n=373,856) \\
\text { Age: }<45\end{array}$ & $\begin{array}{l}\text { Historical } \\
\text { cohort }\end{array}$ & $\begin{array}{l}\text { Adjusted relative risk was significantly higher in } \\
\text { HAART cohort } 2.12(95 \% \mathrm{Cl}, 1.62-2.76) \\
\text { RR did not increase after } 8 \text { years of follow up }\end{array}$ \\
\hline $\begin{array}{l}\text { Friss-Moller } \\
\text { et al }{ }^{33}\end{array}$ & $\begin{array}{l}\text { HIV+ Patients }(n=23,468) \\
\text { Age: } 34-45(I Q R)\end{array}$ & $\begin{array}{l}\text { Prospective } \\
\text { cohort }\end{array}$ & $\begin{array}{l}\text { Exposure to CART and rate of } \mathrm{MI}-\mathrm{RR} \mathrm{I} .26(95 \% \\
\mathrm{Cl}, \mathrm{I} . \mathrm{I} 2-\mathrm{I} .4 \mathrm{I} ; \mathrm{P}<0.00 \mathrm{I})\end{array}$ \\
\hline $\begin{array}{l}\text { Bozzette } \\
\text { et } \mathrm{al}^{35}\end{array}$ & $\begin{array}{l}\text { HIV+ Patients }(n=4 I, 213) \\
98.2 \% \text { male } \\
\text { Age: } 35-55\end{array}$ & $\begin{array}{l}\text { Historical } \\
\text { cohort (VA } \\
\text { population) }\end{array}$ & $\begin{array}{l}\text { Serious CV event: HR I.05 (95\% Cl, I.05-I.06) } \\
\text { Death: HR I.03 (95\% Cl, I.03-I.03) } \\
\text { Pre-existing vascular disease: HR 4.0I ( } 95 \% \text { Cl, } \\
\text { 3.39-4.76) }\end{array}$ \\
\hline $\begin{array}{l}\text { Lichtenstein } \\
\text { et } \mathrm{al}^{36}\end{array}$ & $\begin{array}{l}\text { HIV+ Patients }(n=2,005) \\
\text { Age: } 42 \text { (median) }\end{array}$ & $\begin{array}{l}\text { Prospective } \\
\text { observational } \\
\text { cohort }\end{array}$ & $\begin{array}{l}\text { CVD incidence (per } 100 \text { person years) } \\
\text { I.32 vs } 3.27 \text { ( } P=0.002 \text { ) Exposure vs non-exposure } \\
\text { to HAART, respectively }\end{array}$ \\
\hline $\begin{array}{l}\text { El-Sadr } \\
\text { et } \mathrm{al}^{37}\end{array}$ & $\begin{array}{l}\text { HIV+ Patients }(n=5,472) \\
\text { Drug Conservation Group (treatment } \\
<250 \text { CD4 cells/mm })(n=2,720) \\
\text { Viral Suppression Group }(n=2,752) \\
\text { Age: } 38-50 \text { (IQR) }\end{array}$ & $\begin{array}{l}\text { Open-label, } \\
\text { randomized }\end{array}$ & $\begin{array}{l}\text { Major Cardiovascular, Renal, or Hepatic Disease } \\
\text { HR I.7 }(95 \% \mathrm{Cl} \text {, I. I-2.5) in Drug Conservation } \\
\text { Group as opposed to cART }\end{array}$ \\
\hline $\begin{array}{l}\text { Lang } \\
\text { et } \mathrm{a}^{38}\end{array}$ & $\begin{array}{l}\text { HIV+ Patients }(n=74,958) \\
\text { Age: } 4 I-54(\text { IQR })\end{array}$ & $\begin{array}{l}\text { Case- } \\
\text { control }\end{array}$ & $\begin{array}{l}\text { Risk of MI } \\
\text { Abacavir OR } 2.01 \text { ( } 95 \% \mathrm{Cl}, \mathrm{I} . \mathrm{II}-3.64 \text { ) } \\
\text { (Overall exposure to cART not measured) }\end{array}$ \\
\hline
\end{tabular}

Abbreviations: +, positive; ART, antiretroviral therapy; cART, combination antiretroviral therapy; $\mathrm{CHD}$, coronary heart disease; $\mathrm{Cl}$, confidence interval; $\mathrm{CV}$, cardiovascular; HAART, highly active antiretroviral therapy; HR, hazards ratio; IQR, interquartile range; MI, myocardial infarction; OR, odds ratio; RR, relative risk; VA, Veterans Affairs; y, years; vs, versus, HIV, human immunodeficiency virus.

rates for cardiovascular disease by class of antiretroviral at various age ranges. ${ }^{48}$ Few data are available on the association of MI specifically in the HIV-positive older adult population. Limitations of data include observational design of trials, short duration of follow-up, lack of data on newer antiretroviral agents, and inconsistent control of traditional cardiovascular risk factors (Table 2). ${ }^{38-44,46-51}$

The NRTI abacavir has been associated with possible increased cardiac risk and may pose a risk to older adults with HIV. The FHDC determined there was an increased risk of MI in short term exposure to abacavir (odds ratio[OR] 2.01; 95\% CI, 1.11-3.64). ${ }^{38}$ Data from the D:A:D cohort also determined there was an increased risk of MI with abacavir use. ${ }^{44}$ The ACTG A5001/ALLRT (AIDS Clinical Trial Group A5001/Longitudinal Linked Randomized Trial) historical cohort, using data from previous clinical trials, revealed no association between abacavir use and risk for MI. ${ }^{51}$ When data from clinical trials performed by the manufacturer of abacavir were analyzed, no risk was found..$^{52}$ The meta-analysis by Ding et al concluded that the risk of cardiac events with the use of abacavir was not clinically meaningful. ${ }^{53}$ Due to the inclusion/exclusion of many of these studies, data on older adults were sparse.

\section{Inflammatory nature of HIV and the natural process of aging}

Important considerations for the cardiovascular health of the older patient with HIV include modifiable risk factors that have the potential to disproportionately affect HIV patients older than 50 years. In addition to the increased risk of MI listed previously, HIV infection alone is an independent risk factor for atherosclerosis, regardless of CVD history. ${ }^{54}$ Smoking is a well recognized risk factor for increased cardiovascular disease in the general population, but further analysis of the D:A:D cohort revealed an increased risk in all-cause mortality, and specifically, an increased risk for cardiovascular events in HIV-infected patients..$^{55}$ That analysis is particularly important in relation to the high prevalence of smoking in patients with HIV compared with that in the general population - up to $58 \%$ in some demographic groups. ${ }^{56}$ Dyslipidemia is common in patients with HIV and specifically in patients taking cART with certain ARTs, including PIs, efavirenz, and elevated triglycerides occur 
Table 2 Cardiovascular risks for specific antiretroviral therapies

\begin{tabular}{|c|c|c|c|}
\hline Study & Population & Design & Outcome \\
\hline \multicolumn{4}{|l|}{ Classes } \\
\hline Friis-Moller & Cohort $(n=23,437)$ & $\mathrm{D}: \mathrm{A}: \mathrm{D}$ & RR of Ml per year of PI exposure I.16 (95\% Cl, I.I0-I.23) \\
\hline \multirow[t]{2}{*}{ et $\mathrm{al}^{39}$} & $\mathrm{MI}(\mathrm{n}=345)$ & retrospective & RR of MI per year of NNRTI exposure I.05 ( $95 \% \mathrm{Cl}, 0.98-\mathrm{I} . \mathrm{I3})$ \\
\hline & Age (median): 39 (with Ml) & case-control & \\
\hline Worm & $M I(n=580)$ & $\mathrm{D}: \mathrm{A}: \mathrm{D}$ & Adjusted RR of MI: \\
\hline \multirow[t]{11}{*}{ et $\mathrm{a}^{144}$} & Without MI $(n=32,728)$ & retrospective & Indinavir, cumulative exposure (per year) I.I2 \\
\hline & Age (median): 49 (with Ml), & case-control & $(95 \% \mathrm{Cl}, \mathrm{I} .07-\mathrm{I} . \mathrm{I} 8)$ \\
\hline & 44 (without Ml) & & $\begin{array}{l}\text { Lopinavir-ritonavir, cumulative exposure } 1.13 \\
(95 \% \mathrm{Cl}, 1.05-1.2 \mathrm{I})\end{array}$ \\
\hline & & & Nelfinavir, cumulative exposure $1.04(95 \% \mathrm{Cl}, 0.98-\mathrm{I} . \mathrm{II})$ \\
\hline & & & Saquinavir, cumulative exposure $1.04(95 \% \mathrm{Cl}, 0.98-\mathrm{I} . \mathrm{II})$ \\
\hline & & & Efavirenz, cumulative exposure, I.02 ( $95 \% \mathrm{Cl}, 0.96-1.08)$ \\
\hline & & & Nevirapine, cumulative exposure $0.97(95 \% \mathrm{Cl}, 0.92-1.03)$ \\
\hline & & & Didanosine, recent exposure I.4I (95\% Cl, I.09-I.82) \\
\hline & & & $\begin{array}{l}\text { Abacavir, cumulative exposure } 1.07(95 \% \mathrm{Cl}, \mathrm{I} .00-1.14) \text {; recent } \\
\text { exposure } 1.70(95 \% \mathrm{Cl}, \mathrm{I} .17-2.47)\end{array}$ \\
\hline & & & $\begin{array}{l}\text { Tenofovir, cumulative exposure I.04 }(95 \% \mathrm{Cl}, 0.9 \mathrm{I}-\mathrm{I} . \mathrm{I} 8) \text {; } \\
\text { recent exposure } \mathrm{I} .14(95 \% \mathrm{Cl}, 0.85-\mathrm{I} .53)\end{array}$ \\
\hline & & & $\begin{array}{l}\text { No association with zidovudine, stavudine, lamivudine, } \\
\text { or tenofovir }\end{array}$ \\
\hline \multicolumn{4}{|c|}{ Protease Inhibitors (older) } \\
\hline Holmberg & $H I V+(n=5,672) \quad|7,7| 2.4$ & HOPS, & Mls $(n=2 I)$ per number of patients \\
\hline \multirow[t]{4}{*}{ et $\mathrm{al}^{40}$} & person years & prospective & Protease inhibitors: $19 / 3,247$ \\
\hline & Age (median/range): & observational & No protease inhibitors $2 / 2,425$ \\
\hline & $47(28-67)$ & cohort & OR $7.1(95 \% \mathrm{Cl}, \mathrm{I} .6-44.3)$ \\
\hline & & & Adjusted HR 6.5 (95\% Cl, 0.9-47.8) \\
\hline \multirow[t]{3}{*}{ Jutte et $\mathrm{al}^{41}$} & $\mathrm{HIV}+(\mathrm{n}=1,324)$ & Retrospective & MI \\
\hline & PI use $(n=373)$ & cohort & $\mathrm{PI}$ use $(n=5), \mathrm{I} .06 / 100$ person years $(95 \% \mathrm{Cl}, 0.42-2.24)$ \\
\hline & & & $\begin{array}{l}\text { No PI use }(n=3), 0.21 / 100 \text { person years }(95 \% \mathrm{Cl}, 0.06-0.54 \\
P=0.025)\end{array}$ \\
\hline \multirow[t]{6}{*}{ Klein et $\mathrm{al}^{42}$} & $\mathrm{HIV}+(\mathrm{n}=4,159)$ & Retrospective & Acute MI: \\
\hline & 14,823 person-years & cohort & No PI use $(n=19)$ \\
\hline & Age (median): 42 & & PI use $(n=28)$ \\
\hline & & & Age adjusted MI hospitalization rates: \\
\hline & & & No PI exposure: $4.4(95 \% \mathrm{Cl}, 2-6.7)$ \\
\hline & & & PI exposure $4.3(95 \% \mathrm{Cl}, 2.4-6.1)$ \\
\hline Mary- & $\mathrm{HIV}+(\mathrm{n}=34,976) 88,029$ & $\mathrm{FHDH}$, & Relative hazard for MI \\
\hline Krause & person-years & Prospective & PI $2.56(95 \% \mathrm{Cl}, \mathrm{I} .03-6.34 ; P=0.04)$ \\
\hline \multirow[t]{6}{*}{ et $\mathrm{al}^{43}$} & History of Ml: Age (mean): & cohort & NRTI 0.93 (95\% Cl, 0.19-4.65; P= 0.93); \\
\hline & 41.9 & & NNRT I.38 (95\% Cl, 0.67-2.83; $P=0.38)$ \\
\hline & No Ml: Age (mean): 37.7 & & Exposure to Pl: \\
\hline & & & $<$ I8 months: $8.2(95 \% \mathrm{Cl}, 4.7-1 \mathrm{I} .7)$ per 10,000 patient-years \\
\hline & & & I8-29 months: I5.9 (95\% Cl, 7.9-23.9) per 10,000 patient-years \\
\hline & & & $\geq 30$ months: $33.8(95 \% \mathrm{Cl}, 15.4-52.1)$ per 10,000 patient-years \\
\hline \multirow{5}{*}{$\begin{array}{l}\text { Bozzette } \\
\text { et } \mathrm{al}^{48}\end{array}$} & $\mathrm{HIV}+(\mathrm{n}=36,766)$ & Retrospective & HR for admission for cardiovascular disease for 24 months \\
\hline & Age & cohort of patients & of exposure: \\
\hline & $<35$ years $=17.6 \%$ & using VA services & NRTIs 0.88 (95\% Cl, 0.63-I.22) \\
\hline & $25-55$ years $=71.3 \%$ & compared & Pls I.23 (95\% Cl, 0.78-1.93) \\
\hline & $>55$ years $=11 \%$ & $\begin{array}{l}\text { to typical US } \\
\text { patients }\end{array}$ & NNRTIs I.09 (95\% Cl, 0.56-2.09) \\
\hline & Case & Retrospective & Number of patients with cardiovascular disease (case \\
\hline \multirow{6}{*}{ et $\mathrm{a}^{49}$} & Angina $(n=8) ; M I(n=8)$ & case-control & vs control) NNRTI \\
\hline & Control $(n=32)$ & & Case 0 vs control $0(P=0.09)$ \\
\hline & Age (median): 43 years & & NRTI \\
\hline & (ICVD); 45 years (control) & & Case 190 vs control I $30(P=0.02)$ \\
\hline & & & $\mathrm{PI}$ \\
\hline & & & Case I I 8 vs control $64(P=0.46)$ \\
\hline
\end{tabular}


Table 2 (Continued)

\begin{tabular}{|c|c|c|c|}
\hline Study & Population & Design & Outcome \\
\hline \multicolumn{4}{|l|}{ Atazanavir } \\
\hline Monforte & 301,907 person-years & $D: A: D$ study & Incidence of $\mathrm{MI}$ \\
\hline \multirow[t]{4}{*}{ et $\mathrm{al}^{46}$} & & Prospective & No drug exposure: $0.28(95 \% \mathrm{Cl}, 0.26-0.3)$ per \\
\hline & & cohort & 100 person-years \\
\hline & & & Drug exposure ( 3 or more years): $0.2(0.12-0.32)$ per \\
\hline & & & 100 person-years \\
\hline \multicolumn{4}{|l|}{ Didanosine } \\
\hline \multirow[t]{15}{*}{ Lang et $\mathrm{al}^{38}$} & $\mathrm{HIV}+(\mathrm{n}=74,958)$ & $\mathrm{FHDH}$ & Cumulative exposure $0.9 \mathrm{I}(95 \% \mathrm{Cl}, 0.82-\mathrm{I} .0 \mathrm{I} ; P=0.06)$ \\
\hline & $M I(n=423)$ & Prospective, & Cumulative, recent, and past exposure $0.88(95 \% \mathrm{Cl}, 0.77-\mathrm{I} .0 \mathrm{I}$; \\
\hline & Median age & observational & $P=0.07)$ \\
\hline & Cases $(n=289)$ & cohort & No risk associated with lamivudine, stavudine, tenofovir, \\
\hline & Age (median/lQR): & & zalcitabine, zidovudine, efavirenz, or nevirapine \\
\hline & $47(4 I-54)$ & & No risk associated with indinavir $+/-$ ritonavir, nelfinavir, \\
\hline & Age (median/IQR): & & saquinavir $+/$ - ritonavir \\
\hline & $46(40-54)$ & & Amprenavir or fosamprenavir $+/$ - ritonavir \\
\hline & & & Cumulative: I.57 (95\% Cl, I.24-2; $P=0.00 \mathrm{I})$ \\
\hline & & & Cumulative, recent, and past: I.56 ( $95 \% \mathrm{Cl}, \mathrm{I} .2 \mathrm{I}-2.0 \mathrm{I}$; \\
\hline & & & $P=0.001)$ \\
\hline & & & Lopinavir/ritonavir \\
\hline & & & Cumulative: I.37 (95\% Cl, I.I3-I.65; ), P=0.002 \\
\hline & & & Cumulative, recent, and past: I.34 (95\% Cl, I.09-I.64; \\
\hline & & & $P=0.005)$ \\
\hline SMART/ & $\mathrm{HIV}+(\mathrm{n}=4,544)$ & Prospective & HR (multivariable) in viral suppression arm \\
\hline INSIGHT & Didanosine use $(n=643)$ & cohort & CVD, major 1.06 (95\% Cl, 0.43-2.58) \\
\hline \multirow[t]{6}{*}{ and $\mathrm{D}: \mathrm{A}: \mathrm{D}^{47}$} & Age (median/lQR): & & Clinical MI I.89 (95\% Cl, 0.35-I0.2) \\
\hline & $44(38-50)$ & & CVD, minor $1.03(95 \% \mathrm{Cl}, 0.35-3.03)$ \\
\hline & & & CVD, expanded definition $0.86(95 \% \mathrm{Cl}, 0.40-\mathrm{I} .85)$ \\
\hline & & & HR (multivariable) for new ischemic abnormalities on EKG in \\
\hline & & & viral suppression arm \\
\hline & & & $0.8 \mathrm{I}(95 \% \mathrm{Cl}, 0.59-\mathrm{I} . \mathrm{I} 2)$ \\
\hline \multirow[t]{5}{*}{ Sabin et $\mathrm{al}^{50}$} & $\mathrm{HIV}+(\mathrm{n}=33,347)$ & Prospective & Cumulative exposure (per year) I.06 (95\% Cl, I.0I-I.I2; \\
\hline & 157,912 person-years & cohort & $P=0.03)$ \\
\hline & Age (median/range): & & Recent exposure (within 6 months) I.49 (95\% Cl, I.I4-I.95; \\
\hline & $49(24-92)$ & & $P=0.003)$ \\
\hline & & & Past exposure I.08 $(95 \% \mathrm{Cl}, 0.84-\mathrm{I} .39 ; P=0.54)$ \\
\hline \multicolumn{4}{|l|}{ Abacavir } \\
\hline SMART/ & $\mathrm{HIV}+(\mathrm{n}=4,544)$ & Prospective & Adjusted HR (multivariable) in abacavir, not didanosine arm \\
\hline INSIGHT & Abacavir use $(n=1,019)$ & cohort & CVD, major I.80 (95\% Cl, I.04-3.II) \\
\hline \multirow[t]{3}{*}{ and $\mathrm{D}: \mathrm{A}: \mathrm{D}^{47}$} & Median age: $45(39-5 I)$ & & Clinical MI 4.25 (95\% Cl, I.39-13.0) \\
\hline & & & CVD, minor $2.70(95 \% \mathrm{Cl}, \mathrm{I} .5 \mathrm{I}-4.83)$ \\
\hline & & & CVD, expanded definition I.9I (95\% Cl, I.25-2.92) \\
\hline ACTG & $\mathrm{HIV}+(\mathrm{n}=5,056)$ & Historical & Hazard Ratio of Exposure to abacavir and MI \\
\hline A500I/ & Abacavir use: $(n=1,704)$ & Observational & I year: $0.7(95 \% \mathrm{Cl}, 0.2-2.6)$ \\
\hline \multirow[t]{3}{*}{ ALLRT $^{51}$} & Median age: 37 & cohort & 6 year: $0.6(95 \% \mathrm{Cl}, 0.3-\mathrm{I} .4)$ \\
\hline & $\%$ population $\geq 45: 23 \%$ & & \\
\hline & $(n=1,182)$ & & \\
\hline
\end{tabular}

Abbreviations: $\mathrm{Cl}$, confidence interval; CVD, cardiovascular disease; D:A:D, Data Collection on Adverse Events of Anti-HIV Drugs; FHDH, French Hospital Database on HIV; HR, hazards ratio; hsCRP, high-sensitivity C-reactive protein; HIV, human immunodeficiency virus; HOPS, HIV outpatient study; ICVD, ischemic cardiovascular disease; IL6, interleukin-6; IQR, interquartile range; MI, myocardial infarction; NRTI, non-nucleoside reverse transcriptase inhibitor; NNRTI, non-nucleoside reverse transcriptase inhibitor; OR, odds ratio; PI, protease inhibitor; PY, patient-years; RR, relative risk; vs, versus; SMART, Strategies for Management of Antiretroviral Therapy.

with zidovudine and stavudine treatment. ${ }^{57}$ There are also data to suggest that the incidence of diabetes increases with exposure to cART (RR 1.11; 95\% CI 1.07-1.15), which can disproportionately affect older patients because of increased exposure to $\mathrm{cART}^{58}$ Caution in cART selection should be taken in patients with significant cardiovascular history, regardless of age, as well as other risk factors for cardiovascular disease such as smoking, hyperlipidemia, or a preexisting cardiovascular condition. With the potential for increased comorbidities that exist with aging, older patients with HIV 
require aggressive management and monitoring for modifiable risk factors associated with cardiovascular disease.

\section{HIV: impact on renal function}

The risks for renal dysfunction in patients with HIV are multifactorial. The first identified renal-specific disease associated with HIV infection was HIV-associated nephropathy (HIVAN). HIVAN primarily affects African-Americans and persons with progressive HIV infection. ${ }^{59}$ The utilization of cART has significantly decreased the occurrence of HIVAN in the HIV population. Acute renal failure (ARF) occurs more frequently in patients with HIV compared with a non-HIV population; however, the occurrence of ARF was significantly decreased in patients who have received cART for longer than 3 months. ${ }^{60}$ Moreover, patients with stage $3 \mathrm{CKD}$ and an initially depressed CD4 cell count $\left(<200\right.$ cells $\left./ \mathrm{mm}^{3}\right)$ experienced an increase in glomerular filtration rate (GFR) when the viral load was suppressed $(<400$ copies $/ \mathrm{mL})$ following cART. ${ }^{61}$

Recent prevalence data from the CDC's Medical Monitoring Project estimated that $7.6 \%$ of patients with HIV have concurrent CKD. ${ }^{62}$ Older patients are disproportionately affected by CKD in both the HIV and non-HIV populations. Renal failure is 3 times more likely to occur in HIV-positive older adults compared with those aged 18-49 years without HIV infection. ${ }^{29}$ An analysis of HIV positive patients with and without $\mathrm{CKD}$ revealed that hypertension (HR 2.39; 95\% CI, 1.88-3.04) and history of ARF (HR 2.4; 95\% CI, 1.8-3.2) increased the risk for developing $\mathrm{CKD}$, whereas a CD4 count $>200$ cells $/ \mathrm{mm}^{3}$ reduced the risk of developing CKD (HR 0.63; 95\% CI, 0.48-0.81). ${ }^{63}$

The specific rationale for renal risk in aging patients with HIV is not clear. The process appears to be multifactorial. Potential causes have been theorized which include the use of cART, specific use of antiretroviral agents within regimens, and decreased kidney function associated with aging.

\section{cART versus non cART}

The benefits of cART far outweigh the nephrotoxic risks associated with therapy, as noted in the Strategies for Management of Antiretroviral Therapy (SMART) trial. ${ }^{37}$ Continuous antiretroviral therapy showed a nearly significant increase in fatal or nonfatal renal disease compared to episodic antiretroviral therapy (HR 4.5; 95\% CI, 1-20.9). Given the growth in the aging HIV population and the loss of kidney function associated with increased age, kidney impairment is a major concern when treating with specific cART medications.

\section{Specific ARTs}

In addition to the potential effects of aging and HIV on the kidneys, the potential risk of kidney toxicity secondary to
cART must also be considered. Whereas some negative effects on kidney function have been reported with indinavir, lopinavir/ritonavir, atazanavir, and ritonavir in the published literature, ${ }^{37,64,65}$ the antiretroviral associated with kidney impairment with the greatest frequency is tenofovir, a preferred medication according to the Department of Health and Human Services guidelines, and commonly used in clinical practice. ${ }^{45}$ In premarketing studies of tenofovir, there was no reported kidney impairment in its safety profile. ${ }^{66,67}$ However, following US Food and Drug Administration approval, a number of case reports surfaced describing a variety of toxic effects on the kidneys. ${ }^{68-84}$ The majority of those affected were between the ages of 40-50 years, and the exposure to tenofovir ranged from 10 days to 4.5 years. Reports include cases of acute and chronic kidney dysfunction, with most involving cases of tubular dysfunction. A meta-analysis consisting of 17 prospective studies published by Cooper et al found that tenofovir did reduce renal function, as evidenced by reduction in the estimated creatinine clearance $(\mathrm{CrCl})$ using the Cockcroft and Gault (C\&G) equation or estimated GFR using the Modification of Diet in Renal Disease (MDRD) study equations, respectively. ${ }^{85}$ In the time since these studies were published, the results of several cohorts have been published that demonstrated an association between tenofovir and renal impairment (Table 3). ${ }^{63-65,86-92}$ In the ASSERT study, there was no difference in GFR in the tenofovir/emtricitabine arm compared to the abacavir/lamivudine arm; however, there was a greater presence of markers associated with tubular dysfunction in the tenofovir/emtricitabine arm compared with the abacavir/lamivudine arm. ${ }^{91}$ Additionally, the D:A:D cohort showed that tenofovir was associated with progression of GFR to $70 \mathrm{~mL} / \mathrm{min} / 1.73 \mathrm{~m}^{2}$ or less but was not associated with progression to CKD. ${ }^{92}$ There are numerous limitations of these studies, including the young age of patients, normal baseline renal function, lack of consistent risk factor controls for renal impairment, short duration of follow-up, small sample size in some cohorts, and an overall lack of controls resulting from design limitations.

Other studies that examined the association between tenofovir and renal dysfunction have focused on health issues beyond exposure and dysfunction. Two small observational studies have looked at the recovery of kidney function following the discontinuation of tenofovir. One study found improvements but not complete reversal to baseline renal function, as only $42 \%$ of patients achieved their pre-tenofovir level of kidney function. ${ }^{93}$ The other study $(n=20)$, with a median age of 45 years, found an association between the duration of tenofovir exposure and the kidney recovery rate. ${ }^{94}$ 
Table 3 Renal risks with tenofovir ${ }^{\mathrm{a}}$

\begin{tabular}{|c|c|c|c|}
\hline Study & Population & Design & Outcome \\
\hline Scherzer ${ }^{64}$ & $\begin{array}{l}(\mathrm{n}=10,84 \mathrm{I}) \\
\text { Age (mean): } 46 \\
\text { (VA population) }\end{array}$ & Cohort & $\begin{array}{l}\text { Tenofovir exposure (Multivariate adjustment) } \\
\text { Proteinuria: HR I.34 ( } 95 \% \mathrm{Cl}, \mathrm{I} .25-\mathrm{I} .45 ; P<0.000 \mathrm{I}) \\
\text { Rapid decline: HR I.II (95\% Cl, I.03-I.I8; } P=0.0033) \\
\text { CKD: HR I.33 ( } 95 \% \mathrm{Cl}, \mathrm{I} .18-\mathrm{I} .5 \mathrm{I} ; \mathrm{P}<0.000 \mathrm{I})\end{array}$ \\
\hline $\begin{array}{l}\text { Dauchy } \\
\text { et al }{ }^{65}\end{array}$ & $\begin{array}{l}(\mathrm{n}=399) \\
\text { Age (median, IQR): } \\
47.4 \text { (IQR 42.5-54) } \\
\text { Aquitaine cohort }\end{array}$ & Cohort & $\begin{array}{l}\text { Tenofovir exposure: } \\
\text { Proximal renal tubular dysfunction: OR I.23 per year } \\
(95 \% \mathrm{Cl}, \mathrm{I} .02-1.47 ; P=0.028)\end{array}$ \\
\hline $\begin{array}{l}\text { Mocroft } \\
\text { et al }\end{array}$ & $\begin{array}{l}(\mathrm{n}=6,843) \\
\text { Age (median, IQR): } \\
43(38-50) \\
\text { I03 centers in Europe, } \\
\text { Israel, and Argentina, } \\
\text { EuroSIDA study group }\end{array}$ & Prospective cohort & $\begin{array}{l}\text { Tenofovir exposure (multivariable adjustments) } \\
\text { Incidence of CKD per year: } 1.16(95 \% \mathrm{Cl}, 1.06-1.25 ; P<0.000 \mathrm{I})\end{array}$ \\
\hline Laprise et $\mathrm{a}^{86}$ & $\begin{array}{l}(\mathrm{n}=\mathrm{I}, 043) \\
\text { Age (median, IQR): } \\
39.3 \text { years (34-45.2) } \\
\text { Montreal, Canada }\end{array}$ & Prospective cohort & $\begin{array}{l}\text { Tenofovir exposure: HR I.63 }(95 \% \mathrm{Cl}, \mathrm{I} .26-2 . \mathrm{I}) \\
\text { Cumulative eGFR loss: } \\
\text { I year: }-3.05(P=0.17) \\
2 \text { years: }-4.05(P=0) \\
3 \text { years: }-2.42(P=0.23) \\
4 \text { years: }-3.09(P=0.119)\end{array}$ \\
\hline $\begin{array}{l}\text { Monteagudo- } \\
\text { Chu } \\
\text { et } \mathrm{al}^{87}\end{array}$ & $\begin{array}{l}(\mathrm{n}=230) \\
\text { Age (mean) } \\
\text { Tenofovir: } 52.6 \\
\text { Abacavir: } 50.2 \\
\text { Bronx, NY (VA) }\end{array}$ & $\begin{array}{l}\text { Retrospective chart } \\
\text { review assessing } \\
\text { progression of CKD } \\
\text { from stages } 0-1 \text { to } 2-5 \\
\text { with abacavir as } \\
\text { control }\end{array}$ & $\begin{array}{l}\text { Tenofovir (vs abacavir): progression of CKD } \\
\text { Stage 2: } 48.8 \% \text { vs } 23.7 \%(P<0.00 \mathrm{I}) \\
\text { Stage 3: } 5.8 \% \text { vs } 0 \%(P=0.28) \\
\text { Progression to CKD stage 2: HR } 2.12(95 \% \mathrm{Cl}, \mathrm{I} .4 \mathrm{I}-3.18 \text {; } \\
P<0.00 \mathrm{I}) \\
\text { Progression to CKD stage 3: HR } 4.9 \mathrm{I}(95 \% \mathrm{Cl}, \mathrm{I} .02-23.7 \text {; } \\
P=0.048)\end{array}$ \\
\hline Calza et al ${ }^{88}$ & $\begin{array}{l}(\mathrm{n}=324) \\
\text { Age (median, IQR) } \\
\text { Tenofovir exposed: } 42.5 \\
(34.2-50.1) \\
\text { Tenofovir unexposed: } 42.9 \\
(33.6-51.4)\end{array}$ & Retrospective cohort & $\begin{array}{l}\text { Tenofovir exposed (Multivariable adjusted) } \\
\text { eGFR decline: } \mathrm{HR}-5 . \mathrm{I}(95 \% \mathrm{Cl},-7.6 \text { to }-3.28 ; P<0.002 \mathrm{I})\end{array}$ \\
\hline $\begin{array}{l}\text { Beaudrap } \\
\text { et al }{ }^{89}\end{array}$ & $\begin{array}{l}(\mathrm{n}=324) \\
\text { Age (mean): } \\
\text { Tenofovir: } 40 \\
\text { No tenofovir: } 38 \\
\text { Senegal, } \\
\text { eGFR I,2I5 }\end{array}$ & Cohort & $\begin{array}{l}\text { eGFR change from baseline at } 12 \text { months } \\
\text { Tenofovir: }-10.4 \mathrm{~mL} / \mathrm{min} \\
\text { No tenofovir: }+4.33 \mathrm{~mL} / \mathrm{min}\end{array}$ \\
\hline $\begin{array}{l}\text { Horberg } \\
\text { et } \mathrm{al}^{90}\end{array}$ & $\begin{array}{l}(\mathrm{n}=\mathrm{I}, 647) \\
\text { Age (median, IQR): } \\
\text { Tenofovir: } 43(37.9-49.5) \\
\text { No Tenofovir: } 41.5(35-49) \\
\text { Kaiser Permanente health } \\
\text { maintenance organization }\end{array}$ & Retrospective cohort & $\begin{array}{l}\text { Tenofovir exposure vs No tenofovir exposure over } 104 \text { weeks } \\
\text { eGFR decline: }-7.6 \mathrm{~mL} / \mathrm{min} / \mathrm{I} .73 \mathrm{~m}^{2}(95 \% \mathrm{Cl},-9.2 \text { to }-5.9 ; \\
P<0.00 \mathrm{I}) \\
\text { Development of proximal tubular dysfunction: } \mathrm{RR} 5.23(95 \% \mathrm{Cl} \text {, } \\
2.08 \text { to } 13 . \mathrm{I} ; \mathrm{P}=0.004)\end{array}$ \\
\hline Post et $\mathrm{al}^{91}$ & $\begin{array}{l}(\mathrm{n}=385) \\
\text { Age (median): } 37 \\
76 \text { centers in Europe } \\
\text { ASSERT study }\end{array}$ & $\begin{array}{l}\text { Randomized } \\
\text { Once daily abacavir/ } \\
\text { lamivudine versus } \\
\text { tenofovir/emtricitabine, } \\
\text { both with efavirenz }\end{array}$ & $\begin{array}{l}\text { Abacavir/lamivudine/efavirenz vs tenofovir/emtricitabine/efavirenz } \\
\text { Change eGFR (from baseline): } 0.953(95 \% \mathrm{Cl},-\mathrm{I} .445 \text { to } 3.35 \mathrm{I} \text {, } \\
P=0.435) \\
\text { Renal tubular dysfunction (marker): increase risk in tenofovir/ } \\
\text { emtricitabine/efavirenz arm }(P<0.000 \mathrm{I})\end{array}$ \\
\hline Ryom et $\mathrm{a}^{92}$ & $\begin{array}{l}(\mathrm{n}=22,603) \\
\text { Age (median, IQR): } \\
39(33-44) \\
\text { D:A:D study }\end{array}$ & Prospective cohort & $\begin{array}{l}\text { Cumulative tenofovir exposure (aIRR) } \\
\text { Progression of eGFR } \leq 70 \mathrm{~mL} / \mathrm{min} / \mathrm{I} .73 \mathrm{~m}^{2}: \text { I. } 18 \text { per year }(95 \% \\
\mathrm{Cl}, \mathrm{I} .12-1.25) \\
\text { Progression to CKD: } 1.08 \text { per year }(95 \% \mathrm{Cl}, 0.97-1.2 \mathrm{I})\end{array}$ \\
\hline
\end{tabular}

Note: aPublished studies completed after the Meta-analysis by Cooper et al. ${ }^{85}$

Abbreviations: CKD, chronic kidney disease; $\mathrm{Cl}$, confidence interval; D:A:D, Data Collection on Adverse Events of Anti-HIV Drugs; eGFR, estimated glomerular filtration rate; HR, hazard ratio; IQR, interquartile range; OR, odds ratio; RR, relative risk; VA, Veterans Affairs; vs, versus. 
Several studies have shown that tenofovir in combination with a PI has a greater impact on kidney function. ${ }^{94-98}$ Additionally, cohorts have examined the effects of tenofovir on patients with baseline CKD and found the worse the dysfunction at baseline, the greater the negative impact on the kidney function. ${ }^{98-100}$

With limited data on the older adult with HIV, extrapolation of the renal effects of tenofovir in the aging population is challenging. Based on the available data, it appears that an older patient with HIV initiated on tenofovir as part of cART may be at higher risk than a younger patient as a result of the age-associated kidney dysfunction and the potential for the presence of additional risk factors for renal toxicity.

\section{Monitoring Additional cardiovascular considerations for monitoring}

Framingham risk score evaluations can be a useful tool for assessing CVD risk in older adult HIV patients. This score can be used to help patients understand the need for behavior modifications, such as increased exercise and smoking cessation. The Nutrition for Healthy Living Study evaluated the role of the Framingham risk score among individuals infected with HIV by comparing both patients with and without cART. ${ }^{101}$ That study demonstrated that higher scores were related to surrogate markers for atherosclerosis, such as increased carotid intima-media thickness (c-IMT) and coronary artery calcium (CAC). Intermediate and high scores were associated with internal c-IMT $>1.0 \mathrm{~mm}$ (26\% versus $12 \% ; P=0.003)$ and with detectable CAC (78\% versus 5\%; $P<0.001) .{ }^{101}$ The Framingham score was shown to be accurate even when HIV related variables such as viral load and CD4 counts were present; therefore, it can be a valuable tool in predicting cardiovascular risk in the HIV patient.

The European AIDS Clinical Society (EACS) guidelines recommend consideration of CART changes if the 10 year CVD risk is $>20 \%$. ${ }^{102}$ In addition to the Framingham risk calculator, the D:A:D 5-year estimated risk calculator and the number needed to harm for abacavir calculator can also be used to assess HIV patients' CVD risks. ${ }^{103}$

\section{Additional renal considerations for monitoring}

Monitoring renal function by looking at $\mathrm{CrCl}$ should be done at least quarterly in the aging HIV patient. An Amsterdam study by Vrouenraets et al attempted to determine the most accurate way to determine kidney function in HIV patients. ${ }^{104}$ That study compared assessments of renal function in a small population of virally suppressed HIV patients to determine the most accurate method. The renal function equations, including the Cockcroft and Gault equation (C\&G), the Chronic Kidney Disease Epidemiology Collaboration (CKDEPI) equation, the MDRD study equation, and the cystatin $\mathrm{C}$ - and 24 hour urine-based estimated GFR, were compared to measured GFR using [125I]-iothalamate. That study showed that $\mathrm{C} \& \mathrm{G}$ and $\mathrm{CKD}$-EPI appeared to be the best reflections of true renal function and were most practical for clinical use. A recent study from Thailand also compared estimated GFR to measured GFR, and showed that GFR using the MDRD study equation underestimated true GFR in HIV patients. ${ }^{105}$ The measurement by cystatin- $\mathrm{C}$ was deemed the most accurate for assessing renal function. However, that study also showed that the re-expressed MDRD study equation was the most accurate creatinine-based measurement when adjusting for race. Using cystatin-C to determine kidney function is controversial and has not been readily implemented into clinical practice. Studies are limited and with potential questionable methodology; future studies will be necessary to evaluate its utility in a clinical setting. ${ }^{106,107}$ Finally, urinary analysis (UA) should be performed for all patients upon initiation of therapy, at any therapy change, annually for patients on tenofovir, and every 3 months for patients experiencing HIVAN. ${ }^{45}$ Special attention should be paid to kidney function and cholesterol levels to evaluate both cardiovascular and renal health in the older patient on antiretroviral therapy.

\section{Conclusion}

There is a growing increase in the number of patients over the ages of 50 and 65 years living with an HIV diagnosis. The combination of physiological changes in older adults, comorbidities associated with aging, and potential ADRs of cART may lead to an increased risk for cardiovascular and renal disease in this population relative to younger patients. However, as the long-term impact of HIV on cardiovascular and renal function in the older patient with HIV is unknown, aggressive management and monitoring of comorbidities in the older adult HIV patient is critical, as further studies in patients 50 years and older with HIV are conducted. Managing specific cART therapies, preventing viral progression of the disease, and aggressively treating comorbidities may all play a role in monitoring and decreasing the impact of cardiovascular and renal disease in the older patient with HIV. 


\section{Acknowledgment}

The authors would like to acknowledge Sue Bollmeier, PharmD, BCPS, AC-E, for editing the manuscript.

\section{Disclosure}

Daron L Smith owns company stock in Gilead Sciences Inc. The authors report no other conflicts of interest in this work.

\section{References}

1. Centers for Disease Control and Prevention. 1993 revised classification system for HIV infection and expanded surveillance case definition for AIDS among adolescents and adults. MMWR Recomm Rep. 1994;41(RR-17):1-19. Available from: http://www.cdc.gov/mmwr/ preview/mmwrhtml/00018871.htm. Accessed August 12, 2013.

2. Brooks JT, Buchacz K, Gebo KA, et al. HIV infection and older adults: the public health perspective. Am J Public Health. 2012;102: 1516-1526.

3. Kirk JB, Goetz MB. Human immunodeficiency virus in an aging population, a complication of success. J Am Geriatr Soc. 2009;57: 2129-2138.

4. Rickabaugh TM, Jamieson BD. A challenge for the future: aging and HIV infection. Immunol Res. 2010;48:59-71.

5. Global HIV/AIDS response: epidemic update and health sector progress towards universal access. WHO, U UNAIDS. Geneva, Switzerland, 2011.

6. Centers for Disease Control and Prevention. HIV/AIDS surveillance report 2006. Vol 18. Atlanta: US Department of Health and Human Services, Centers for Disease Control and Prevention: 2008. Available from: http://www.cdc.gov/hiv/topics/surveillance/resources/ reports/2006report/pdf/2006SurveillanceReport.pdf. Accessed August 12, 2013.

7. Effros RB, Flectcher CV, Gebo K, et al. Aging and infection disease: workshop on HIV infection and aging: what is known and future research directions. Clin Infect Dis. 2008;47:542-553.

8. Cahill S, Valadez R. Growing older with HIV/AIDS: new public health challenges. Am J Public Health. 2013;103(3):e7-e15.

9. Centers for Disease Control and Prevention. Diagnosis of HIV infection in the United States and Dependent Areas, 2011. Center for Disease Control. HIV surveillance report; 2011. Available from: http://www.cdc.gov/hiv/surveillance/resources/reports/2011 report/ pdf/2011_HIV_Surveillance_Report_vol_23.pdf\#Page=17. Accessed August 12, 2013.

10. Greene M, Justice AC, Lampiris HW, et al. Management of human immunodeficiency virus infection in advanced age. JAMA. 2013;309(13):1397-1405.

11. Linley L, Prejean J, An Q, et al. Racial/ethnic disparities in HIV diagnoses among person aged 50 and older in 37 US states. Am J Public Health. 2012;102(8):1527-1534.

12. Almasi F. HIV in the elderly (patients aged more than 65 years old). Retrovirology. 2010;7(Suppl 1):P16.

13. Manfredi R. HIV infection and advanced age emerging epidemiological, clinical, and management issues. Ageing Res Rev. 2004;3:31-54.

14. Kearney F, Moore AR, Donegan CF, et al. The ageing of HIV: implications for geriatric medicine. Age and Ageing. 2010;39:536-541.

15. Linsk NL. HIV among older adults: age specific issues in prevention and management. AIDS. 2000;6:579-584.

16. Butt AA, Dascomb KK, DeSalvo KB, Bazzano L, Kissinger PJ, Szerlip HK. Human immunodeficiency virus infection in elderly patients. S Med J. 2001;94:397-400.

17. Centers for Disease Control and Prevention. Monitoring selective national HIV prevention and care objective by using HIV surveillance data - United States and 6 US dependent area-2010. HIV Surveillance Supplemental Report. 2012;17(No 3, part A). Available from: http:// www.cdc.gov/hiv/pdf/statistics_2010_HIV_Surveillance_Report_ vol_17_no_3.pdf. Accessed August 12, 2013.
18. Reuter S, Oette M, Kasier R, et al. Risk factors associated with older age in treatment-naïve HIV-positive patients. Intervirology. 2012;55: 147-153.

19. Chan YJ. HIV in the elderly: an emergent challenge. JCMA. 2011;74: 195-196.

20. MaMercedes N, Navarro G, Anton E. Epidemiological and clinical features, response to HAART, and survival in HIV-infected patients diagnosed at age 50 or more. BMC Infect Dis. 2006;6:159.

21. Gebo KA. Epidemiology of HIV and response to antiretroviral therapy in the middle aged and elderly. Aging Health. 2008;4(6):615-627.

22. Nachega JB, Hsu AJ, Uthman OA, Spinewine Anne, Pham PA. Antiretroviral therapy adherence and drug-drug interactions in the aging HIV population. AIDS. 2012;26(Suppl 1):S39-S53.

23. Hasse B, Ledergerber B, Furrer H, et al. Morbidity and aging in HIV infected persons: the Swiss HIV cohort study. Clin Infect Dis. 2008;47: $542-553$.

24. Roger VL, Go AS, Lloyd-Jones DM, et al. Heart disease and stroke statistics - 2012 update: a report from the American Heart Association. Circulation. Available from: http://circ.ahajournals.org/content/125/1/ e2.full.pdf+html. Accessed August 12, 2013.

25. Anderson S, Halter JB, Hazzard WR, et al. Prediction, progression, and outcomes of chronic kidney disease in older adults. JAm Soc Nephrol. 2009;20:1199-1209.

26. Lindeman RD, Tobin J, Shock NW. Longitudinal studies on the rate of decline in renal function with age. J Am Geriatr Soc. 1985;33: $278-285$.

27. Coresh J, Selvin E, Stevens LA, et al. Prevalence in chronic kidney disease in the United States. JAMA. 2007;298:2038-2047.

28. Work Group for the HIV and Aging Consensus Project. Summary report from the human immunodeficiency virus and aging consensus project: treatment strategies for clinicians managing older individuals with the human immunodeficiency virus. J Am Geriatr Soc. 2012;60:974-979.

29. Nkhoma E, Vannappagari V, Mynepalli L, et al. Comorbidities and coinfections among HIV patients 50 years and older. Presented at the 1st International Workshop on HIV and Aging. October 4-5. 2010; Baltimore, MD, USA.

30. Armah KA, McGinnis K, Baker J, et al. HIV status, burden of comorbid disease and biomarkers of inflammation, altered coagulation and monocyte activation. Clin Infect Dis. 2012;55(1):126-136.

31. Currier JS, Taylor A, Boyd F, et al. Coronary heart disease in HIV-infected individuals. Acquir Immune Defic Syndr. 2003;33(4): 506-512.

32. Obel N, Thomsen HF, Kronborg, G, et al. Ischemic Heart Disease in HIV-infected and HIV-uninfected individuals: a population based cohort study. Clin Infect Dis. 2007;44(12):1625-1631.

33. Friss-Moller N, Sabin CA, Weber R, et al. Combination antiretroviral therapy and the risk of myocardial infarction. $N$ Engl $J$ Med. 2003;349(21):1993-2003

34. Freiberg MS, Chang CC, Kuller LH, et al. HIV infection and the risk of acute myocardial infarction. JAMA Intern Med. 2013;173(8): 614-622.

35. Bozzette SA, Ake CF, Tam HK, et al. Long-term survival and serious cardiovascular events in HIV-infected patients treated with highly active antiretroviral therapy. J Acquir Immune Defic Syndr. 2008;47(3): 338-341.

36. Lichtenstein KA, Armon C, Buchacz K, et al. Low CD4+ T cell count is a risk factor for cardiovascular disease events in the HIV outpatient study. Clin Infect Dis. 2010;51(4):435-447.

37. El-Sadr WM, Lundgren J, Neaton JD, et al. CD4+ count-guided interruption of antiretroviral treatment. $N$ Engl J Med. 2006;355(22): 2283-2296.

38. Lang S, Mary-Krause M, Cotte L, et al. Impact of individual antiretroviral drugs on the risk of myocardial infarction in human immunodeficiency virus-infected patients: a case-control study nested within the French Hospital Database on HIV ANRS cohort CO4. Arch Intern Med. 2010;170(14):1228-1238. 
39. Friis-Moller N, Reiss P, Sabin CA, et al. Class of antiretroviral drugs and the risk of myocardial infarction. N Engl J Med. 2007;356(17):1723-1735.

40. Holmberg SD, Moorman AC, Williamson JM, et al. Protease inhibitors and cardiovascular outcomes in patients with HIV-1. Lancet. 2002;360(9347):1747-17488.

41. Jutte A, Schwenk A, Franzen C, et al. Increasing morbidity from myocardial infarction during HIV protease inhibitor treatment? AIDS. 1999;13(13):1796-1797.

42. Klein D, Hurley LB, Quesenberry CP, et al. Do protease inhibitors increase the risk for coronary heart disease in patients with HIV-1 infection? J Acquir Imm Def Syndr. 2002;30(5):471-477.

43. Mary-Krause M, Cotte L, et al; Clinical Epidemiology Group from the French Hospital Database. Increased risk of myocardial infarction with duration of protease inhibitor therapy in HIV-infected men. AIDS 2003;17(17):2479-2486.

44. Worm SW, Sabin C, Weber R, et al. Risk of myocardial infarction in patients with HIV infection exposed to specific individual antiretroviral drugs from the 3 major drug classes: the data collection on adverse events of anti-HIV drug (D:A:D) study. J Infect Dis. 2010;201(3):318-330.

45. Panel on Antiretroviral Guidelines for Adults and Adolescents Guidelines for the use of antiretroviral agents in HIV-1-infected adults and adolescents. Department of Health and Human Services. Available from http://aidsinfo.nih.gov/contentfiles/lvguidelines/ AdultandAdolescentGL.pdf. Accessed August 12, 2013

46. Monforte Ad, Reiss P, Ryom L, et al. Atazanavir is not associated with an increased risk of cardio or cerebrovascular disease events. AIDS 2013;27:407-415.

47. The Strategies for Management of Anti-Retroviral Threapy/INSIGHT and the D:A:D Study Groups. Use of nucleoside reverse transcriptase inhibitors and risk of myocardial infarction in HIV-infected patients. AIDS. 2008;22(14):F17-F24.

48. Bozzette SA, Ake CF, Tam HK, et al. Cardiovascular and cerebrovascular events in patients treated for human immunodeficiency virus infection. N Engl J Med. 2003;348(8):702-710.

49. David MW, Hornung R, Fichtenbaum CJ. Ischemic cardiovascular disease in persons with human immunodeficiency virus infection. Clin Infect Dis. 2002;34:98-102.

50. Sabin CA, Worm SW, Weber R. Use of nucleoside reverse transcriptase inhibitors and risk of myocardial infarction in HIV-infected patients enrolled in the D:A:D study: a multi-cohort collaboration. Lancet. 2008; 371(9622):1417-1426.

51. Ribaudo HJ, Benson CA, Zheng Y, et al. No risk of myocardial infarction associated with initial antiretroviral treatment containing abacavir: short and long-term results from ACTG A5001/ALLRT. Clin Infect Dis. 2011;52(7):929-940.

52. Brothers CH, Hernandez JE, Cutrell AG, et al. Risk of myocardial infarction and abacavir therapy: no increased risk across 52 GlaxoSmithKline-sponsored clinical trials in adult subjects. $J$ Acquir Immune Defic Syndr. 2009;41(1):20-28.

53. Ding X, Andraca-Carrera E, Cooper C, et al. No association of abacavir use with myocardial infarction: findings of an FDA meta-analysis. J Acquir Immune Defic Syndr. 2012;61(4):441-447.

54. Grunfeld, C, Delaney JA, Wanke C, et al. Pre-clinical atherosclerosis due to HIV infection: carotid intima-medial thickness measurements from the FRAM Study. AIDS. 2009;23(14):1841-1849.

55. Smith C, Sabin CA, Lundgren JD, et al. Factors associated with specific causes of death amongst HIV-positive individuals in the D:A:D Study. AIDS. 2010;24(10):1537-1548.

56. Gritz ER, Vidrine DJ, Lazev AB, Amick BC 3rd, Arduino RC. Smoking behavior in a low-income multiethnic HIV/AIDS population. Nicotine Tob Res. 2004;6(1):71-77.

57. Dube M, Fenton M. Lipid abnormalities. Clin Infect Dis. 2003; 36(Suppl 2):S79-S83.

58. De Wit S, Sabin CA, Weber R, et. al. Incidence and risk factors for new-onset diabetes in HIV-infected patients: the Data Collection on Adverse Events of Anti-HIV Drugs (D:A:D) study. Diabetes Care. 2008;31(6):1224-1229.
59. Lucas GM, Eustace JA, Sozio S, Mentari EK, Appiah KA, Moore RD. Highly active antiretroviral therapy and the incidence of HIV-1associated nephropathy: a 12-year cohort study. AIDS. 2004;18(3): $541-546$.

60. Roe J, Campbell LJ, Ibrahim F, Hendry BM, Post FA. HIV care and the incidence of acute renal failure. Clin Infect Dis. 2008;47(2): 242-249.

61. Kalayjian RC, Franceschini N, Gupta SK, et al. Suppression of HIV-1 replication by antiretroviral therapy improves renal function in persons with low CD4 cell counts and chronic kidney disease. AIDS. 2008;22(4): 481-487.

62. Garg S, Furlow-Parmley C, Frazier E, Skarbinski J. Prevalence of chronic kidney disease among HIV+ adults in care in the US: Medical Monitoring Project, 2009. Conference on Retroviruses and Opportunistic Infections. Atlanta 2013. Abstract 810.

63. Flandre P, Pugliese P, Cuzin L, et al. Risk factors of chronic kidney disease in HIV-infected patients. Clin J Am Soc Nephrol. 2011;6(7): 1700-1707.

64. Scherzer R, Estrella M, Li Y, et al. Association of tenofovir exposure with kidney disease risk in HIV infection. AIDS. 2012;26:867-875.

65. Dauchy FA, Lawson-Ayayi S, de La Faille R, et al. Increased risk of abnormal proximal renal tubular function with HIV infection and antiretroviral therapy. Kidney Int. 2011;80(3):302-309.

66. Gallant JE, Staszewski S, Pozniak AL, et al. Efficacy and safety of tenofovir DF vs stavudine in combination therapy in antiretroviral-naïve patients: a 3-year randomized trial. JAMA. 2004;292(2):191-201.

67. Gallant JE, DeJesus E, Arribas JR, et al. Tenofovir DF, emtricitabine, and efavirenz vs zidovudine, lamivudine, and efavirenz for HIV. NEngl J Med. 2006;354:251-260.

68. Agarwala R, Mohan S. Herlitz LC, et al. 41-year-old HIV patient with proteinuria and progressive renal dysfunction. Kidney Int. 2010;77(5): 475-476.

69. Haverkort ME, van der Spek BW, Lips P, et al. Tenofovir-induved Fanconi syndrome and osteomalacia in two HIV-infected patients: role of intracellular tenofovir diphosphate levels and review of the literature. Scand J Infect Dis. 2011;43(10):821-826.

70. Pavie J, Scemla A, Bouldouyre MA, et al. Severe acute renal failure in an HIV-infected patient after only 2 weeks of tenofovir-based antiretroviral therapy. AIDS Patient Care STDS. 2011;25(8):457-460.

71. Schaaf B, Aries SP, Kramme E, Steinhoff J, Dalhoff K. Acute renal failure associated with tenofovir treatment in a patient with acquired immunodeficiency syndrome. Clin Infect Dis. 2003;37(3):e41-e43.

72. Saumoy M, Vidal F, Peraire J, et al. Proximal tubular kidney damage and tenofovir: a role for mitochondrial toxicity? AIDS. 2004;18(12): 1741-1749.

73. Wood SM, Shah SS, Steenhoff AP, Meyers KE, Kaplan BS, Rutstein RM. Tenofovir-associated nephrotoxicity in two HIV-infected adolescent males. AIDS Patient Care STDS. 2009;23(1):1-4.

74. Barrios A, Garcia-Benayas T, Gonzalex-Lahoz J, Soriano V. Tenofovir-related nephrotoxicity in HIV-infected patients. AIDS. 2004;18(6):960-963.

75. Blaas S, Schneidewind A, Gluck T, Salzberger B. Acute renal failure in HIV patients with liver cirrhosis receiving tenofovir: a report of two cases. AIDS. 2006;20(13):1786-1787.

76. Coca S, Perazella MA. Rapid communication: acute renal failure associated with tenofovir: evidence of drug-induced nephrotoxicity. Am J Med Sci. 2002;324(6):342-344.

77. Gaspar G, Monereo A, Garcia-Reyne A, de Guzman M. Fanconi syndrome and acute renal failure in a patient treated with tenofovir: a call for caution. AIDS. 2004;18(2):351-352.

78. Kapitsinou PP, Ansari N. Acute renal failure in an AIDS patient on tenofovir: a case report. J Med Case Rep. 2008;2:1-4.

79. Lee JC, Marosok RD. Acute tubular necrosis in a patient receiving tenofovir. 2003;17(17):2543-2544.

80. Krummel T, Parvez-Braun L, Frantzen L, et al. Tenofovir-induced acture renal failure in an HIV patient with normal renal function. Nephrol Dial Transplant. 2005;20(2):473-474. 
81. Malik A, Abraham P, Malik N. Acute renal failure and Fanconi syndrome in an AIDS patient on tenofovir treatment-base report and review of literature. $J$ Infect. 2005;51(2):e61-e65.

82. Peyriere H, Reynes J, Rouanet I, et al. Renal tubular dysfunction associated with tenofovir therapy. J Acquir Immune Defic Syndr. 2004;35(3):269-273.

83. Zimmermann AE, Pizzoferrato T, Bedford J, Morris A, Hoffman R, Braden G. Tenofovir-associated acute and chronic kidney disease: a case of multiple drug interactions. Clin Infect Dis. 2006;42(2): 283-290.

84. James CW, Steinhaus MC, Szabo S, Dressier RM. Tenofovir-related nephrotoxicity: case report and review of the literature. Pharmacotherapy. 2004;24(3):415-418.

85. Cooper RD, Wiebe N, Smith N, Keiser P, Naicker S, Tonelli M. Systematic review and meta-analysis: renal safety of tenofovir disoproxil fumarate in HIV-infected patients. Clin Infect Dis. 2010; 51(5):496-505.

86. Laprise C. Baril JG, Dufresne S, Trottier H. Association between tenofovir exposure and reduced kidney function in a cohort of HIV-positive patients: results from 10 years of follow-up. Clin Infect Dis. 2013;56(4):567-575.

87. Monteagudo-Chu MO, Change MH, Fung HB, Brau N. Renal toxicity of long-term therapy with tenofovir in HIV-infected patients. J Pharm Pract. 2012;25(5):552-559.

88. Calza L, Trapani F, Tedeschi S, et al. Tenofovir-induced renal toxicity in 324 HIV-infected, antiretroviral-naïve patients. Scandinavian J Infect Dis. 2011;43(8):656-660.

89. Beaudrap P, Diallo MB, Landman R, et al. Changes in the renal function after tenofovir-containing antiretroviral therapy initiation in a Senegalese Cohort (ANRS 1215). AIDS Res Hum Retroviruses. 2010;26(11):1221-1227.

90. Horberg M, Tang B, Towner W, et al. Impact of tenofovir on renal function in HIV-infected, antiretroviral naïve patients. JAcquir Immune Defic Syndr. 2010;53(1):62-69.

91. Post FA, Moyle GJ, Stellbrink HF, et al. Randomized comparison of renal effects, efficacy, and safety with once-daily abacavir/lamivudine versus tenofovir/emtricitabine, administered with efavirenz, in antiretroviral-naïve, HIV-1 infected adults: 48 week results from the ASSERT study. J Acquir Immune Defic Syndr. 2010;55(1):49-57.

92. Ryom L, Mocroft A, Kirk O, et al. Association between antiretroviral exposure and renal impairment among HIV-positive persons with normal baseline renal function: the D:A:D Study. J Infect Dis. 2013; 207(9):1359-1369.

93. Wever K, van Agtmael MA, Carr A. Incomplete reversibility of tenofovir-related renal toxicity in HIV-infected men. J Acquir Immune Defic Syndr. 2010;55(1):78-81.

94. Young J, Schafer J, Fux CA, et al. Renal function in patients with HIV starting therapy with tenofovir and either efavirenz, lopinavir or atazanavir. AIDS. 2012;26(5):567-575.

95. Buchacz K, Young B, Baker RK, et al. Renal function in patients receiving tenofovir with ritonavir/lopinavir or ritonavir/atazanavir in the HIV Outpatient Study (HOPS) Cohort. J Acquir Immune Defic Syndr. 2006;4(5)3:626-628.
96. Goicoechea M, Liu S, Best B, et al. Greater tenofovir-associated renal function decline with protease inhibitor-based versus nonnucleoside reverse-transcriptase inhibitor-based therapy. $J$ Infect Dis. 2008;197(1):102-108.

97. Gallant JE, Parish MA, Keruly JC, et al. Changes in renal function associated with tenofovir disoproxil fumarate treatment, compared with nucleoside reverse-transcriptase inhibitor treatment. Clin Infect Dis. 2005;40(8):1194-1198.

98. Fafin C, Pugliese P, Durant J, et al. Increased time exposure to tenofovir is associated with a greater decrease in estimated glomerular filtration rate in HIV patients with kidney function of less than $60 \mathrm{~mL} /$ min/1.73 m2. Nephron Clin Pract. 2012;120(4):c205-c214.

99. Brennan A, Evans D, Mashkew M, et al. Relationship between renal dysfunction, nephrotoxicity and death among HIV adjust on tenofovir. AIDS. 2011;25(13):1603-1609.

100. Young B, Buchacz K, Moorman A, et al. Renal function in patients with preexisting renal disease receiving tenofovir-containing highly active antiretroviral therapy in the HIV outpatient study. AIDS Patient Care and STDS. 2009;23(8):589-592.

101. Falcone EL, Mangili A, Skinner S, Alam A, Polak JF, Wanke CA. Framingham risk score and early markers of atherosclerosis in a cohort of adults infected with HIV. Antivir Ther. 2011;16(1):1-8.

102. European AIDS Clinical Society Guidelines; version 6.1; November 2012. Available from: http://www.europeanaidsclinicalsociety.org/ images/stories/EACS-Pdf/EacsGuidelines-v6.1-2edition. Accessed August 12, 2013.

103. Friis-Moller N, Thiebaut R, Reiss P, et al. Predicting the risk of cardiovascular disease in HIV-infected patients: the Data collection on Adverse Effects of Anti-HIV Drugs Study. Eur J Cardiovasc Prev Rehabil. 2010;17(5):491-501.

104. Vrouenraets SM, Fux CA, Wit FW, et al. A comparison of measured and estimated glomerular filtration rate in successfully treated HIVpatients with preserved renal function. Clin Nephrol. 2012;77(4): 311-320.

105. Praditpornsilpa K, Avihingsanon A, Chaiwatanarat T, et al. Comparisons between validated estimated glomerular filtration rate equations and isotopic glomerular filtration rate in HIV patients. AIDS. 2012;26(14):1781-1788.

106. Gagneux-Brunon A, Mariat C, Delanaye P. Cystatin C in HIV-infected patients: promising but not yet ready for prime time. Neprhol Dial Transplant. 2012;27(4):1305-1313.

107. Mauss S, Berger F, Kuschak D, et al. Cystatin C as a marker of renal function is affected by HIV replication leading to an underestimation of kidney function in HIV patients. Antivir Ther. 2008;13(8): 1091-1010.

108. Mocroft, A, Kirk O, Reiss P, et al. Estimated glomerular filtration rate, chronic kidney disease and antiretroviral drug use in HIV patients. AIDS. 2010;24(11):1667-1678.
HIV/AIDS - Research and Palliative Care

\section{Publish your work in this journal}

HIV/AIDS - Research and Palliative Care is an international, peerreviewed open-access journal focusing on advances in research in HIV, its clinical progression and management options including antiviral treatment, palliative care and public healthcare policies to control viral spread. The journal welcomes original research, basic science,

\section{Dovepress}

clinical \& epidemiological studies, reviews \& evaluations, expert opinion \& commentary, case reports \& extended reports. The manuscript management system is completely online and includes a very quick and fair peer-review system. Visit http://www.dovepress.com testimonials.php to read real quotes from published authors. 